\title{
Gerakan Gemar Menabung untuk Siswa Sekolah Dasar di Kecamatan Meureubo, Aceh Barat
}

\author{
Budianto*1, Rina Maulina $^{2}$, Nani Verawati3 \\ 1,2,3Universitas Teuku Umar, Meulaboh - Aceh Barat \\ 1,2,3Program Studi Akuntansi, Fakultas Ekonomi, Universitas Teuku Umar \\ *e-mail: budianto@utu.ac.id ${ }^{1}$,rinamaulina@utu.ac.id ${ }^{2}$,naniverawati@utu.ac.id ${ }^{3}$
}

\begin{abstract}
This community service aims to provide elementary school students with an understanding of the importance of saving. It is also expected to contribute to educating the younger generation by saving awareness from an early age. By saving each child will learn independently and not depend on their parents. Saving habits will be better if they get encouragement and motivation from their parents. The method of implementing community service is carried out through 'socialization'. Partners in this activity are SDN Peunaga, Meureubo District, West Aceh Regency. The number of students who took part in the activities was 54 people, consisting of 11 students in Class I, 21 in Class II and 22 in Class III. This activity involved lecturers and students from the Accounting Department, University Teuku Umar. The results of this activity are expected to increase saving interest in elementary school students in Meureubo District, West Aceh Regency.
\end{abstract}

Keywords: Savings, Student, Elementary School, Socialization

\begin{abstract}
Abstrak
Pengabdian masyarakat ini bertujuan memberikan pemahaman kepada siswa sekolah dasar tentang pentingnya membiasakan menabung. Selain itu juga diharapkan dapat memberikan kontribusi mencerdaskan generasi muda melalui kesadaran menabung sejak usia dini. Dengan menabung setiap anak akan belajar mandiri dan tidak bergantung kepada orang tua mereka. Kebiasaan menabung akan lebih baikjika mendapat dorongan dan motivasi dari orang tua mereka. Adapun metode pelaksanaan pengabdian masyarakat ini dilakukan melalui 'sosialisasi'. Mitra dalam kegiatan ini adalah Sekolah Dasar Negeri Peunaga, Kecamatan Meureubo Kabupaten Aceh Barat. Jumlah siswa yang ikut dalam kegiatan sebanyak 54 orang, terdiri dari siswa kelas I sebanyak 11 orang, kelas II sebanyak 21 orang dan kelas III sebanyak 22 orang. Kegiatan ini melibatkan dosen dan mahasiswa dari Program Studi Akuntansi Universitas Teuku Umar. Hasil pengabdian masyarakat ini diharapkan dapat meningkatkan minat menabung pada siswa sekolah dasar di Kecamatan Meureubo Kabupaten Aceh Barat.
\end{abstract}

Kata kunci: Menabung, Siswa, Sekolah Dasar, Sosialisasi

\section{PENDAHULUAN}

Budaya menabung masyarakat Indonesia terbilang cukup rendah bila dibandingkan dengan negara Asia lain. Fakta ini tercermin dari rendahnya marginal propensity to save atau keinginan untuk menabung masyarakat, meskipun produk domestik bruto (PDB) meningkat. Badan Pusat Statistik (BPS) mencatat, pada 2015 rasio tabungan terhadap PDB hanya sebesar 34,8 persen. Angka tersebut masih lebih rendah dibandingkan dengan Singapura dan Tiongkok yang mencapai 49 persen atau Filipina sebesar 46 persen. Padahal, Indonesia memiliki jumlah penduduk sangat banyak. Jumlah ini seharusnya dapat menjadi salah satu kekuatan bagi industri jasa keuangan nasional dalam meningkatkan rasio porsi tabungan. (https://www.liputan6.com, 12 Juli 2018).

Menyikapi fenomena tersebut, Otoritas Jasa Keuangan (OJK) sebagai regulator telah menggagas program nasional berupa tabungan Simpanan Pelajar (SimPel). Tujuan program tersebut adalah untuk membangun serta membentuk budaya gemar menabung sejak usia dini. Bagi negara, menabung dapat mengurangi hutang negara dengan meningkatnya investasi nasional, sedangkan manfaat bagi individu adalah memperoleh keuntungan dari prinsip bunga, bagi hasil dan sebagainya (Abdallah, 2015). 
Kebiasaan menabung sejak usia dini memberikan manfaat pada anak-anak untuk menata masa depan mereka, karena menabung merupakan salah satu dasar pembelajaran dalam perencanaan keuangan. Dengan menabung setiap anak akan belajar untuk mandiri dan tidak bergantung kepada orang tua mereka. Kebiasaan menabung jauh lebih baik jika setiap anak mendapat dorongan dari orang tua mereka dalam hal mengingatkan setiap hari agar anak mau menyisihkan uang jajannya untuk ditabung.

Salah satu cara orang tua dalam mengajarkan kebiasaan menabung yang baik adalah dengan mengenalkan kepada siswa fungsi bank untuk menyimpan uang. Orang tua dapat mengajak siswa menabung ke bank agar mereka memahami bahwa ketika menabung di bank maka kita akan menjadi seorang nasabah yang mempunyai tanggung jawab dalam mengelola keuangan pribadinya. Sehingga suatu saat kelak setiap siswa tersebut akan memiliki tabungan yang akan berguna untuk kepentingan masa depannya tanpa bergantung pada orang tua mereka.

Penerapan financial parenting perlu diterapkan sejak anak usia dini, dikarenakan dengan terbiasanya anak mengelola uang sejak kecil maka akan berdampak positif pada pengelolaan keuangannya saat dewasa nanti (Krisdayanthi, 2019). Sesuai dengan hasil penelitian Amilia, Bulan dan Rizal (2018) menyatakan bahwa sosialisasi orang tua berpengaruh signifikan terhadap perilaku menabung. Artinya orang tua merupakan peran sosialisasi utama dalam proses belajar anak mengenai uang dan proses pengembangan perilaku pengelolaan keuangan yang diberikan oleh keluarga.

Sosialisasi merupakan salah cara untuk mempengaruhi kebiasaan seseorang agar mau mengikuti sesuatu hal yang diharapkan dapat dipraktikkan. Begitu halnya dengan membiasakan menabung pada siswa/i sekolah dasar dapat dilakukan dengan alternatif kegiatan sosialisasi langsung kepada mereka di sekolah. Kegiatan sosialisasi langsung kepada siswa/i bertujuan agar memudahkan proses penyampaian melalui interaksi dua arah antar narasumber dan peserta.

"Gerakan Gemar Menabung untuk Siswa/i Sekolah Dasar" merupakan salah satu upaya sosialisasi memberikan pendidikan kepada siswa untuk belajar hidup mandiri, baik dalam hal mempersiapkan kebutuhan pribadinya maupun kebutuhan-kebutuhan lainnya. Diharapkan sosialisasi ini dapat meningkatkan kreatifitas siswa dalam mengelola keuangannya (manajemen keuangan). Murtani (2019) menyatakan bahwa perlu adanya sosialisasi dan motivasi yang berkelanjutan guna meningkatkan pengetahuan dan minat siswa untuk menabung.

Sebelumnya pada tanggal 20 Februari 2010, Presiden dan Gubernur Bank Indonesia pada saat itu telah mencanangkan Kampanye Gerakan Indonesia Menabung (GIM) melalui peluncuran produk perbankan TabunganKu. Sebagai tindak lanjutnya pada tanggal 27 Juni 2012 wakil presiden Bapak Boediono telah juga telah menetapkan setiap hari Rabu awal bulan sebagai Hari Rajin Menabung. Pada tanggal 14 Juni 2015, pemerintah bersama perbankan juga menginisiasi program SimPel/Simpel iB (Simpanan Pelajar) yang diikuti oleh 300 lebih bank di Indonesia yang terdiri dari 20 Bank Umum, 11 Bank Umum Syariah, 24 Bank Pembangunan Daerah dan 249 Bank Perkreditan Rakyat/Bank Pembiayaan Rakyat Syariah.

Berbagai program yang diluncurkan pemerintah di atas bertujuan untuk mengajak para pelajar untuk lebih gemar menabung sejak dini dan meningkatkan kesadaran masyarakat sehingga akan turut meningkatkan inklusi keuangan. Mengajari anak menabung sejak dini juga bisa membentuk kepribadian positif, menabung bermakna mengajari anak bagaimana melatih kesabaran, dan menabung berguna untuk simpanan masa depan (Marlina, 2019).

Kegiatan Sosialisasi Gemar Menabung untuk Siswa/i Sekolah Dasar dilaksanakan di SDN Peunaga, Desa Peunaga, Kecamatan Meureubo Kabupaten Aceh Barat, Provinsi Aceh. Jumlah siswa yang ikut dalam kegiatan ini sebanyak 54 orang, terdiri dari siswa kelas I sebanyak 11 orang, siswa kelas II sebanyak 21 orang dan siswa kelas III sebanyak 22 orang. Pemilihan siswa kelas I, II dan III (bukan kelas IV, V dan VI) sesuai dengan arahan dari kepala sekolah yang menginginkan agar yang menjadi peserta sosialisasi adalah siswa kelas rendah (kelas I, II dan III). 
SDN Peunaga dipilih sebagai mitra kegiatan karena merupakan salah satu sekolah dasar yang berada dalam Kecamatan Meureubo, Kabupaten Aceh Barat, tidak jauh dari Universitas Teuku Umar. Salah satu tujuan yang diharapkan dari kegiatan pengabdian ini adalah untuk memberikan kontribusi mencerdaskan generasi muda melalui kesadaran menabung sejak usia dini. Selain itu kehadiran Universitas Teuku Umar sebagai perguruan tinggi negeri baru (PTNB) di Aceh juga diharapkan menjadi sumber inspirasi dan referensi pengembangan kemajuan pendidikan terutama di Aceh wilayah Barat Selatan.

Berdasarkan pemaparan dan uraian di atas penulis tertarik mengangkat tema pengabdian masyarakat dengan judul "Sosialisasi Gerakan Gemar Menabung pada Siswa/i Sekolah Dasar Negeri Peunaga, Kecamatan Meureubo, Kabupaten Aceh Barat”.

\section{METODE}

\subsection{Lokasi Kegiatan}

Kegiatan pengabdian masyarakat ini dilaksanakan di Sekolah Dasar Negeri Peunaga, Desa Peunaga Kecamatan Meureubo, Kabupaten Aceh Barat, Provinsi Aceh. Kegiatan sosialisasi ini dilaksanakan pada tanggal 28 November 2018.

Lokasi kegiatan dapat dilihat pada gambar di bawah ini:

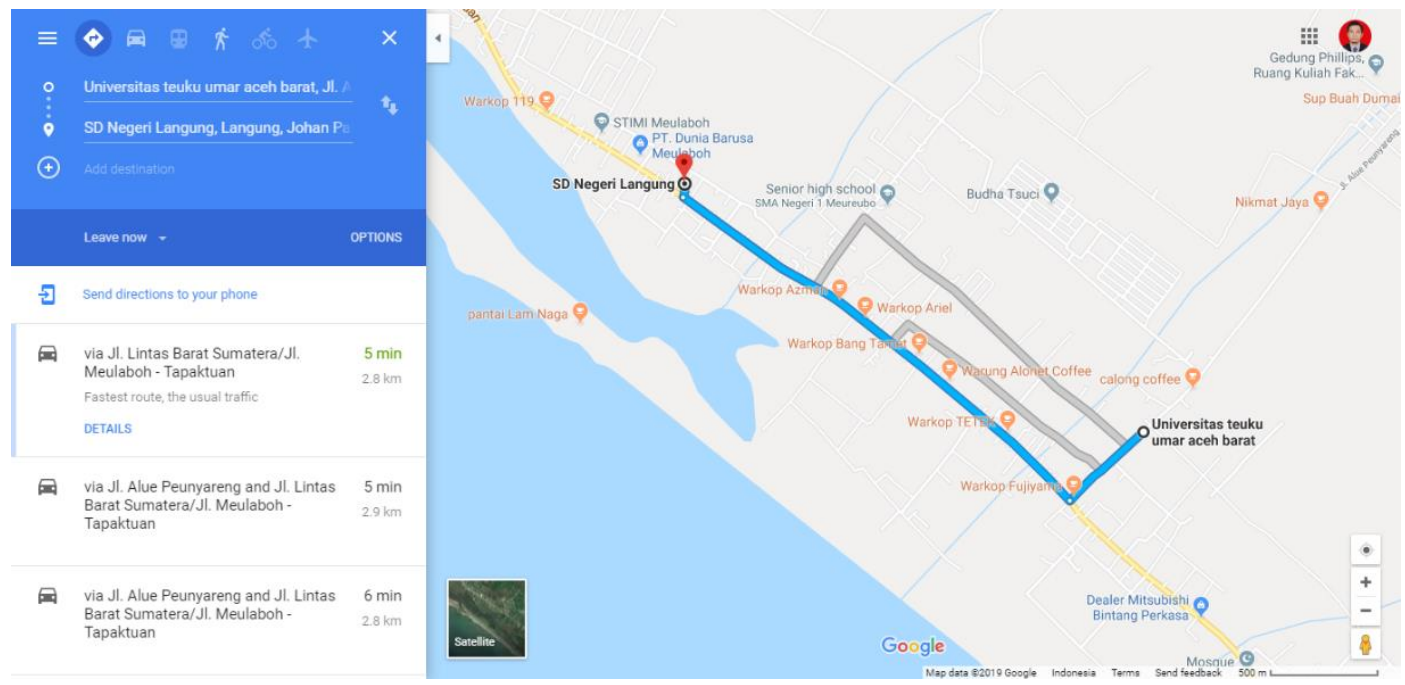

Gambar 1. Lokasi kegiatan mitra

\subsection{Metode Pelaksanaan}

Kegiatan pengabdian masyarakat ini dilaksanakan melalui metode sosialisasi langsung ke siswa-siswi Sekolah Dasar Negeri Peunaga. Sosialisasi dilakukan dengan mengumpulkan seluruh siswa yang akan mengikuti kegiatan. Selanjutnya tim pengabdian melakukan sosialisasi Gerakan Gemar Menabung dengan berkolaborasi bersama mahasiswa Program Studi S1 Akuntansi Fakultas Ekonomi Universitas Teuku Umar. Selain sosialisasi, tim pengabdian masyarakat juga melakukan diskusi tanya jawab serta membagikan cinderamata dalam bentuk celengan kepada siswa/siswi peserta sosialisasi. Celengan yang dibagikan sebagai salah satu bentuk dorongan kepada siswa/siswi Sekolah Dasar Negeri Peunaga agar semakin giat menabung sejak dini.

\subsection{Sasaran Kegiatan}

Sasaran kegiatan sosialisasi ini adalah siswa/i tingkat sekolah dasar yang masih duduk di bangku kelas I sampai dengan kelas III. Adapun pemilihan siswa kelas I, II, dan III sesuai arahan pihak sekolah agar anak-anak yang duduk di bangku kelas rendah (I, II, III) mendapatkan pemahaman terkait pentingnya menabung sejak masih duduk di bangku sekolah. 


\subsection{Jadwal dan Waktu Pelaksanaan}

Kegiatan pengabdian dilaksanakan di Sekolah Dasar Negeri Peunaga, Kecamatan Meureubo, Kabupaten Aceh Barat, pada tanggal 28 November 2018. Adapun agenda kegiatan dapat dilihat pada tabel di bawah ini:

Tabel 1. Jadwal Pelaksanaan Kegiatan

\begin{tabular}{|c|c|l|l|}
\hline No & Waktu & \multicolumn{1}{|c|}{ Uraian Kegiatan } & \multicolumn{1}{|c|}{ Pengisi Kegiatan } \\
\hline 1 & $08.00-08.30$ & Registrasi Peserta & Tim Pengabdian \\
\hline 2 & $08.30-08.45$ & Pengumpulan Peserta & Tim Pengabdian \\
\hline 3 & $08.45-09.00$ & Pembukaan dan Arahan & Tim Pengabdian \\
\hline 4 & $09.00-10.00$ & Sosialisasi dan Diskusi & Tim Pengabdian \\
\hline 5 & $10.00-11.00$ & Sosialisasi dan Diskusi & Tim Pengabdian \\
\hline 6 & $11.00-12.00$ & Simulasi Menabung & Tim Pengabdian \\
\hline 7 & $12.00-12.15$ & Foto Bersama & Tim Pengabdian \\
\hline 8 & $12.15-12.30$ & Penyerahan Sertifikat Kegiatan & Ketua Tim Pengabdian \\
\hline
\end{tabular}

\section{HASIL DAN PEMBAHASAN}

Pelaksanaan pengabdian masyarakat dengan tema tentang Gerakan Gemar Menabung Untuk Siswa-Siswi Sekolah Dasar di Kabupaten Aceh Barat ini dilakukan pada tanggal 28 November 2018. Tahap awal melakukan koordinasi rencana kegiatan dengan pihak mitra yaitu Sekolah Dasar Negeri Peunaga, Kecamatan Meureubo, Kabupaten Aceh Barat. Pada tahap ini tim pengabdian menjajaki rencana kegiatan dengan pihak sekolah, dalam hal ini berkoordinasi langsung dengan kepala sekolah.

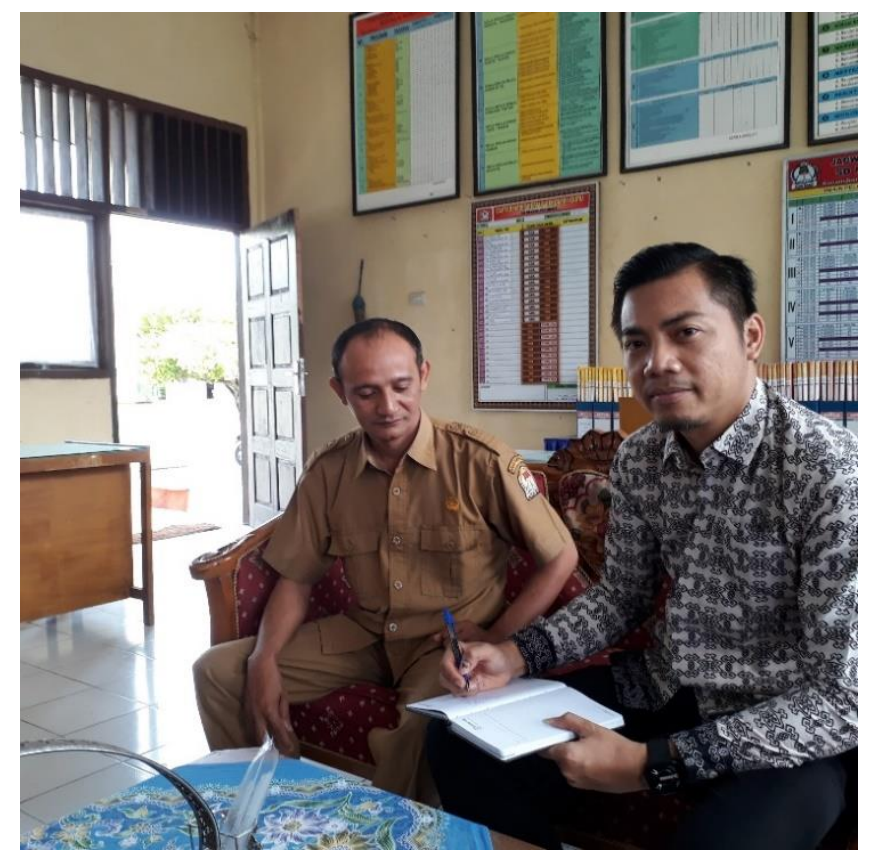

Gambar 1. Koordinasi awal dengan pihak sekolah

Kegiatan sosialisasi diawali dengan pemaparan secara interaktif dari tim pengabdian kepada siswa siswi. Pemaparan ini disampaikan dengan cara dan bahasa yang lebih mudah dimengerti anak-anak sekolah dasar. Untuk itu tim pengabdian melibatkan juga mahasiswa dalam kegiatan sosialisasi. Sepanjang penyampaian dan diskusi di kelas, seluruh siswa/i peserta sangat antusias dan banyak yang bertanya kepada pemateri sosialisasi.

Keterlibatan mahasiswa dalam kegiatan juga memberikan warna tersendiri dalam penyampaian materi sosialisasi menabung. Sebagai generasi milenial, peran mahasiswa harus 
lebih aktif dalam kehidupan sosial yang nyata, tidak hanya di media sosial. Melalui keterlibatan dalam sosialisasi menabung dalam satu tim pengabdian ini terlihat mahasiswa/i sangat antusias dalam menyampaikan materi kepada adik-adik siswa sekolah dasar yang menjadi peserta. Linawati (2015:12) dalam penelitiannya menyimpulkan bahwa para mahasiswa memperoleh bekal yang berharga melalui program Service Learning dalam membuka wawasan mahasiswa untuk melihat realita kehidupan di masyarakat.

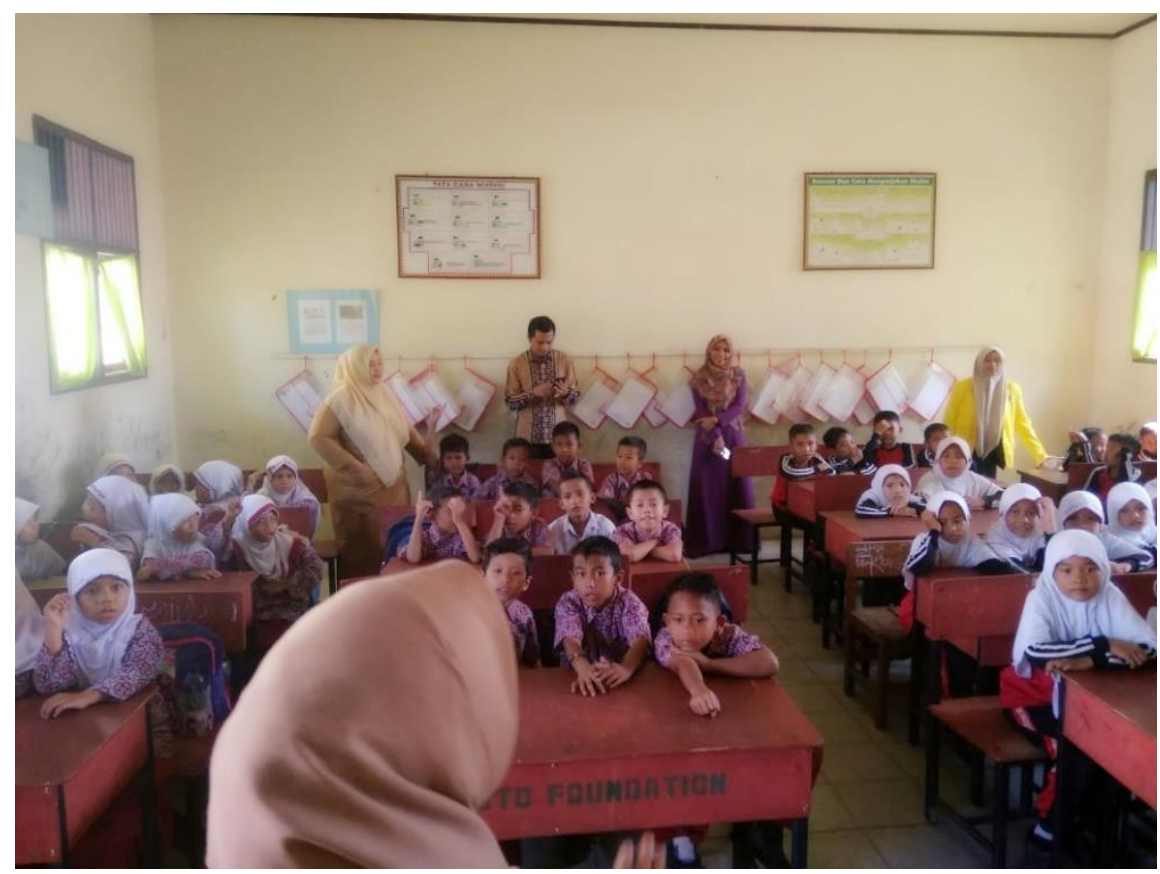

Gambar 2. Antusiasme siswa mengikuti kegiatan

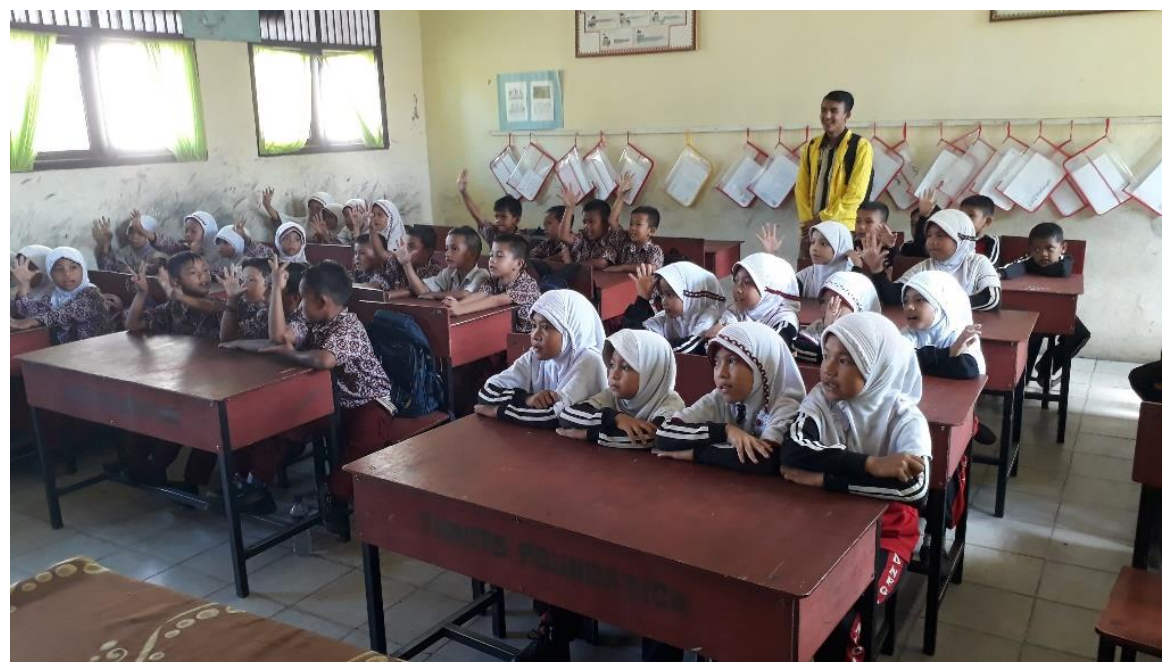

Gambar 3. Antusiasme siswa mengikuti kegiatan

Tahap selanjutnya adalah membagikan cinderamata dalam bentuk celengan kepada seluruh siswa/i peserta sosialisasi. Cinderamata ini dibagikan untuk menambah motivasi siswa/i agar rajin menabung. Pada sesi pembagian celengan, seluruh peserta terlihat gembira dan sangat senang saat menerima satu persatu. Kebahagiaan anak-anak menerima cinderamata merupakan salah satu kebahagiaan kami sebagai tim pengabdian karena bisa berbagi kepada sesama terutama siswa/i SDN Peunaga, Kecamaan Meureubo, Aceh Barat. 


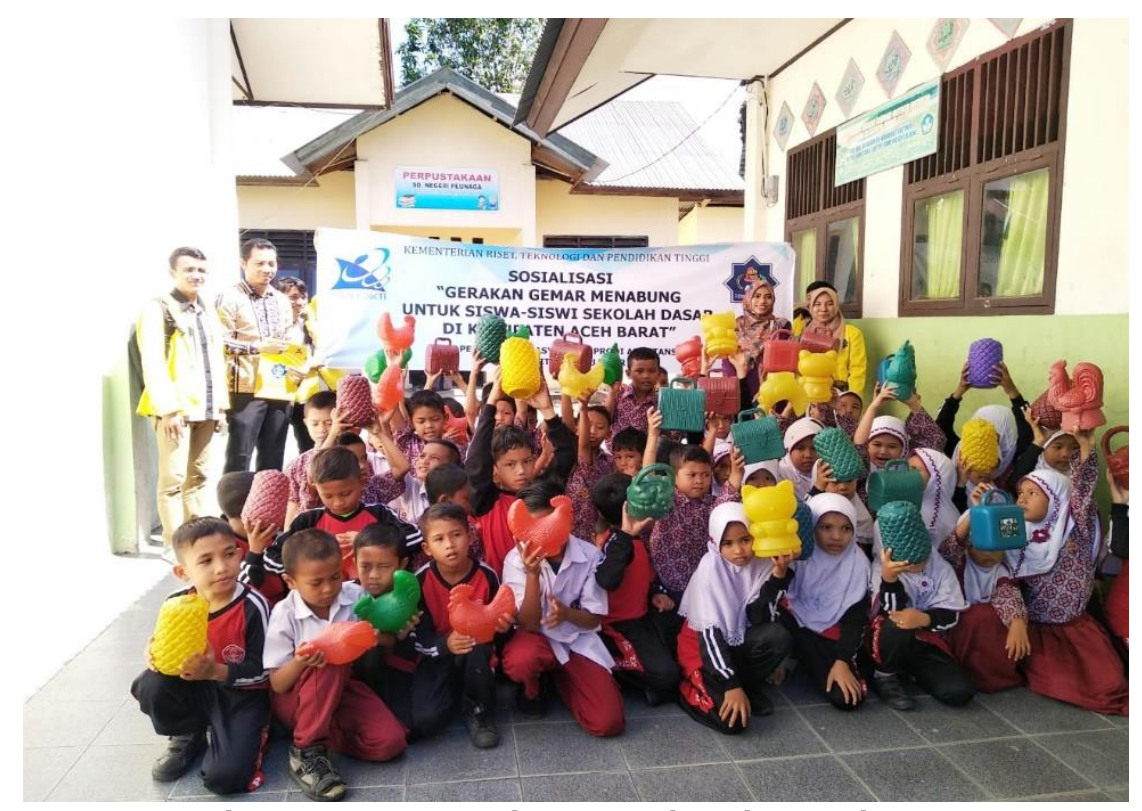

Gambar 4. Peserta sosialisasi mendapatkan cinderamata

Setelah sesi pembagian celengan selesai dilaksanakan, kemudian siswa/i tersebut kembali ke kelas masing-masing dan bersiap-siap untuk pulang. Selanjutnya tim pengabdian bersama kepala sekolah dan seluruh dewan guru SDN Peunaga melakukan foto bersama sebelum menutup kegiatan. Foto bersama tersebut dilaksanakan di depan ruang dewan guru. Gambar berikut merupakan sesi foto bersama tim pengabdian dan pihak sekolah.

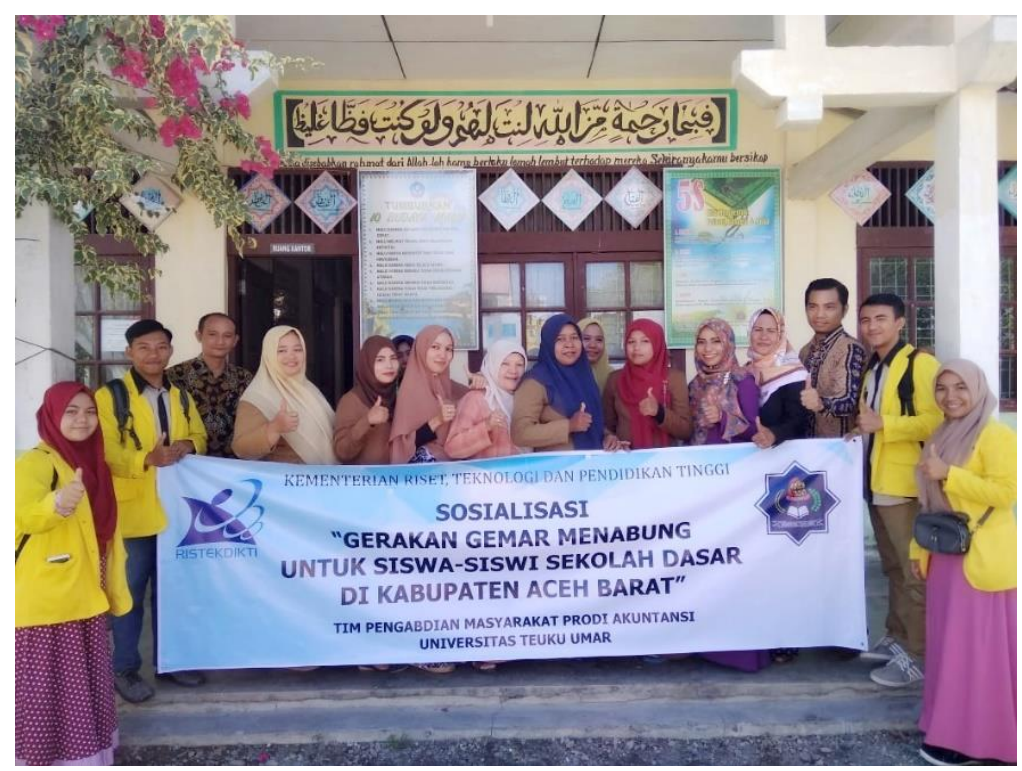

Gambar 5. Foto bersama tim pengabdian dan pihak sekolah

Sebagai penutup kegiatan, Ketua Tim Pengabdian juga menyerahkan sertifikat kepada pihak sekolah SDN Peunaga diwakili oleh Kepala Sekolah. Sertifikat tersebut sebagai bentuk apresiasi kepada SDN Peunaga karena telah berpartisipasi dalam kegiatan sosialisasi yang dilaksanakan oleh tim pengabdian Universitas Teuku Umar. Berikut adalah foto saat serah terima sertifikat kegiatan dari ketua tim pengabdian kepada kepala sekolah. 


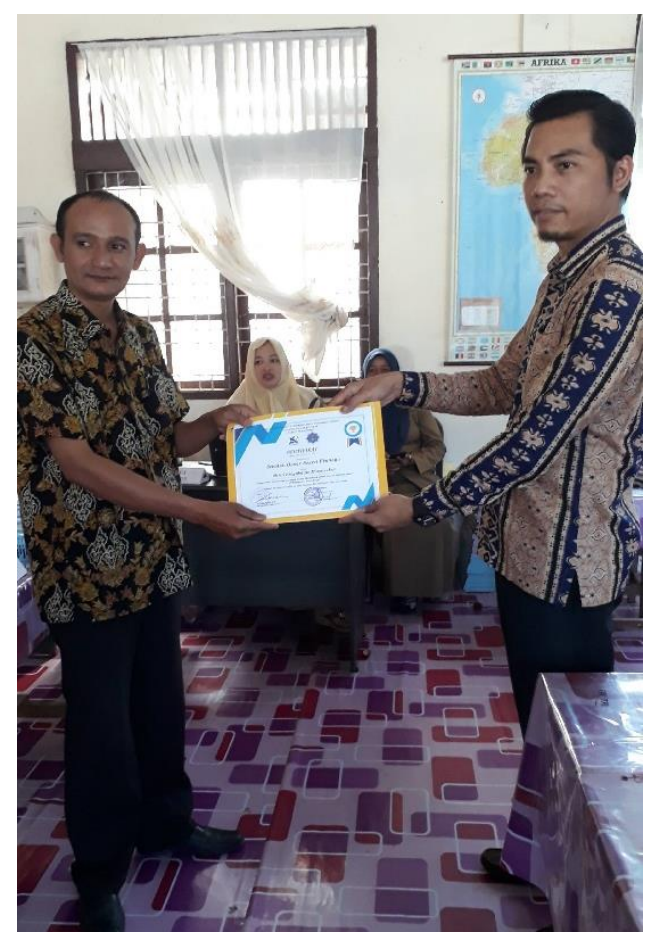

Gambar 6. Serah terima sertifikat kegiatan

\section{KESIMPULAN}

Berdasarkan penjelasan yang telah dibahas sebelumnya, dapat ditarik kesimpulan bahwa budaya menabung sebaiknya dimulai sejak dini, terutama pada anak-anak. Memang bukan hal baru lagi, tetapi bagi sebagian orang belum menerapkan hal ini pada anak-anaknya, karena masih merasa serba kecukupan. Padahal walau dalam keadaan yang berlebihan harta, justru harus membiasakan anak berhemat dan menyisihkan sebagian uang untuk ditabung, sehingga anak bisa mengatur uang dengan sebaik-baiknya dari usia dini.

Menabung juga dapat melatih anak untuk bersabar, mampu menahan diri, berdisiplin, dan mampu memenuhi keinginannya atau sesuatu tanpa bergantung kepada orang tua. Sehingga anak akan terbiasa dan mampu mengatur uang sampai tumbuh dewasa. Pendidikan keuangan dalam keluarga sangat dibutuhkan agar anak menjadi individu yang cerdas dalam pengelolaan uang, tidak boros dan gemar menabung.

Melalui kegiatan sosialisasi gemar menabung untuk anak sekolah dasar ini bisa menjadi salah satu metode untuk mengenalkan dan mengajarkan kepada anak-anak supaya rajin menabung, sehingga kelak anak menjadi pandai mengelola keuangan serta memiliki kecerdasan finansial sejak dini.

Adapun manfaat dari kegiatan sosialisasi dan simulasi menabung bagi siswa antara lain (Narpati, 2018); (1) memahami pengetahuan tentang tabungan dan produk sejenis lainnya, (2) memahami cara membuka rekening di bank dan mengetahui petugas-petugas bank yang menangani pembukaan rekening dan transaksi keuangan melalui simulasi bank. (3) menyadari pentingnya menabung dan menanamkan kebiasaan menabung dalam kehidupan sehari-hari.

\section{UCAPAN TERIMA KASIH}

Tim pengabdian masyarakat mengucapkan terima kasih kepada pihak-pihak yang telah memberikan dukungan terlaksananya kegiatan ini antara lain:

1) Kepala Sekolah SDN Peunaga, Kecamatan Meureubo, Kabupaten Aceh Barat.

2) Dewan Guru SDN Peunaga, Kecamatan Meureubo, Kabupaten Aceh Barat.

3) Dekan Fakultas Ekonomi Universitas Teuku Umar.

4) Ketua Prodi S1 Akuntansi Fakultas Ekonomi Universitas Teuku 
5) Mahasiswa Prodi S1 Akuntansi Fakultas Ekonomi Universitas Teuku Umar yang ikut terlibat.

\section{DAFTAR PUSTAKA}

Abdallah, M., \& Lubis, I. (2015). Analisis Minat Menabung Pada Bank Syariah Di Kalangan Siswa SMA di Kota Medan (Studi Kasus: Siswa Madrasah Aliyah Negeri). Ekonomi Dan Keuangan, 3 (6), 436-447.

Amilia, S., Bulan, T. P. L., \& Rizal, M. (2018). Pengaruh Melek Finansial, Sosialisasi Orang Tua, dan Teman Sebaya Terhadap Perilaku Menabung Mahasiswa Bidik Misi Fakultas Ekonomi Universitas Samudra. Jurnal Samudra Ekonomika, 2 (2), 97-107.

Bank BJB. (2018). Bank BJB Gencar Lakukan Kampanye Gerakan Menabung Sejak Dini. Diakses 21 Oktober 2019, dari https://www.liputan6.com/news/read/3586635/bank-bjb-gencarlakukan-kampanye-gerakan-menabung-sejak-dini

Bank Indonesia. (2019). Gerakan Indonesia Menabung (GIM). diakses 4 Agustus 2019, dari https://www.bi.go.id/id/perbankan/keuanganinklusif/program/gimtab/Contents/Default $\underline{\operatorname{aspx}}$

Dakhi, A., \& Lubis, I. (2014). Analisis Minat Menabung di Kalangan Siswa SMA Negeri di Kota Medan. Jurnal Ekonomi dan Keuangan, 2 (9), 525-534.

Krisdayanthi, A. (2019). Penerapan Financial Parenting (Gemar Menabung) Pada Anak Usia Dini. Pratama Widya: Jurnal Pendidikan Anak Usia Dini, 4 (1), 1-7.

Linawati, N. (2015). Penanaman Jiwa Bijak Mengelola Uang Pada Siswa PAUD Kelurahan Siwalankerto Surabaya Melalui Kegiatan Service Learning Mata Kuliah Personal Finance. SHARE "SHaring - Action - REflection," 3 (1), 9-13. https://doi.org/10.9744/share.3.1.9-13

Linawati, N. (2018). Peran Media Ajar Dalam Pendidikan Keuangan Pada Siswa Taman KanakKanak Melalui Program Service Learning Mata Kuliah Personal Finance. SHARE "SHaring Action - REflection," 4 (1), 1-6. https://doi.org/10.9744/share.4.1.1-6

Marlina, N., \& Iskandar, D. (2019). Gerakan Menabung Sejak Dini di Rowosari. Jurnal Pengabdian Vokasi, 01 (01), 27-32.

Murtani, Alim. (2019). Sosialisasi Gerakan Menabung. Seminar Nasional Hasil Pengabdian Kepada Masyarakat (SINDIMAS), Pontianak 29 Juli.

Narpati, B. (2018). Sosialisai dan Simulasi Menabung Rumah Yatim Kota Bekasi. Jurnal Pengabdian Kepada Masyarakat UBJ, 1 (2), 77-86. https://doi.org/10.31599/jabdimas.v1i2.295

Otoritas Jasa Keuangan. (2019). OJK Ajak Pelajar Gemar Menabung. diakses 4 Agustus 2019, dari https://www.medcom.id/ekonomi/mikro/5b2qg74N-ojk-ajak-pelajar-gemar-menabung 